\title{
PEACE, RACE, AND DISCIPLINARY DECADENCE
}

\author{
PAZ, RAÇA E DECADÊNCIA DISCIPLINAR
}

DOI: https://doi.org/10.20873/uft.2179-3948.2018v9n1p66

\section{Jin Jang ${ }^{1}$ \\ Carlos Cordero-Pedrosa ${ }^{2}$}

\begin{abstract}
This article briefly analyzes the implications of Lewis Gordon's work on race, racism and disciplinarity in our field of inquiry, peace studies. The centrality of human beings and freedom in Gordon's philosophy, and his metadisciplinary reflections help us to rethink our experience as doctoral students in the discipline where questions of race, racism and colonialism are undertheorized. We contend that an interdisciplinary approach that leaves disciplines unquestioned is insufficient to address problems of racism.
\end{abstract}

Keywords: Lewis Gordon; race; racism; peace studies; disciplinary decadence.

Resumo: Este artigo analisa brevemente as implicações do trabalho de Lewis Gordon sobre raça, racismo e disciplinaridade em nosso campo de pesquisa, sobre estudos da paz. A centralidade dos seres humanos e da liberdade na filosofia de Gordon e suas reflexões metadisciplinares nos ajudam a repensar nossa experiência como doutorandos na disciplina onde as questões de raça, racismo e colonialismo são subabordadas. Afirmamos que uma abordagem interdisciplinar que deixa as disciplinas inquestionadas é insuficiente para disccutir os problemas gerados pelo racismo.

Palavras-chave: Lewis Gordon; raça; racismo; estudos de paz; decadência disciplinar.

Nelson Maldonado-Torres defines Lewis Gordon as a philosopher of the human and points out how his study of race and racism "serves as an entry mode to theorize the human" (MALDONADO-TORRES, 2008, p.118). Gordon's work on race illuminates the fact that race and racism are human phenomenon, which ultimately are human relations manifested. Understanding the construction of race as the product of meaning-constituting activities of humans resulting from the changes in human relations requires looking back at the year1492, which inaugurated the European encounter with the "New World." This signaled new relations and categories for human groups that had not existed before. The etymology of race comes from raza in the fifteenth century Andalucia (NIRENBERG, 2012, p.102) to refer to breeds of animals, and Jews and Muslims. The word then already has its roots in the judgment of the normative humanity, which at the time was Christian, and later in secularization as science replaced religion, became European (read white) from the eighteenth century onward.

\footnotetext{
${ }^{1}$ Universitat Jaume I de Castellón, email: jerbyerl@hotmail.com

${ }^{2}$ Universitat Jaume I de Castellón, email: carlosjaviercorder@ gmail.com
} 
The problem of European Christians from their encounters with the peoples from the New World was that no description they knew of in their known world could describe these peoples. As seen in the famous debate between Bartolomé de Las Casas and Juan Gines de Sepúlveda, placing the people outside the human category gave the Christians the license to enslave and annihilate entire populations of people. The Atlantic slave trade then gradually replaced the enslavement of the peoples of the New World. Africans, who, according to Fanon, never had to think of themselves as other than human beings became known as black in the Euromodern world.

In Gordon's Bad Faith and Antiblack Racism (1995), a relational and existential dimension of anti-black racism is explored by using the Sartrean concept of bad faith (mauvaise-foi). Bad faith here is used to evade the responsibility humans fundamentally have to relate to other human beings. Racism attempts to push human beings outside of human relations. A racist hides from the truth that he is in fact dealing with flesh and blood human beings instead of a category. In other words, the antiblack racist is lying to himself as he knows that blacks are humans but refuses to see it. To see human beings as categories such as "white" or "black" instead of people with different hues of skin color involves a form of bad faith. Bad faith, then, is an "essential attitude" for denying human reality. Reality, for Gordon, is the opposite of bad faith. Bad faith involves denying our relationship with and to reality. It denies the intersubjective world of each other, a world where human freedom is ultimately found. This is the world Frantz Fanon was referring to when he said "Was my freedom not given to me then to build the world of the You?" (FANON, 2008, p. 181) Racism, denying such freedom of oneself and other humans, according to Gordon, is a form of misanthropy. In this way, it is not the elimination of race that will rid ourselves of racism. Rather, it is the Gordonian understanding of the human as a free being in her relations with other human beings that makes racism flawed, as it is an effort to hide from one's freedom. For Gordon, freedom is not just emancipation. It is also broader and more fundamental than liberation, justice, or peace. It is rooted in the human condition of individuals as openness, possibilities, and relationships that together construct meanings of the social world, the world of intersubjectivity.

Gordon's black existential philosophy, thus, is not only about theorizing the existence of black people, but concomitantly about what it means to be human. That is why his first philosophy is philosophical anthropology. From that question, other questions emerge. Gordon's tracing of the black intellectual responses to the lived experience of African 
diasporic people of enslavement, colonialism, and racism, thus, raises the three thematically interrelated issues: what it means to be human in interrogating the standards of humanity, practices of freedom, and metacritique of reason in questioning how the justification itself is justified. Rooted in a philosophy of existence and using an Africana phenomenological analysis, Gordon's study of antiblack racism brings to the forefront, rather than hides from, the role of human agency and responsibility in an ongoing praxis of freedom as a meaningconstituting activity in a world of relationships. The study of race and racism, then, becomes a significant point of departure from the colonial conception of the human and its methodological assumptions. Questioning race and racism ultimately leads to questioning the very method and discipline for studying the human. Gordon stresses the significance of Fanon's work in decolonial thought precisely because it raises the problem of coloniality at the methodological level (GORDON, 2015).

We, the authors, are currently doing a doctoral dissertation in peace studies where we undertook our research projects on race and racism. While peace studies' interdisciplinarity allows us to borrow insights from other disciplines that sufficiently deal with these issues, we observe a lack of transdisciplinary effort across disciplines to discuss the problem of race and racism. The characteristics of an interdisciplinary approach sometimes maintain disciplines as isolated and unquestioned since no dialogue goes beyond a tangential relationship among disciplines, which will be discussed below. Although there have recently been examinations of how race lies at the core of human rights (SUAREZ-KRABBE, 2015), international law (ANGHIE, 2004) or international relations (ANIEVAS et al., 2014), in our program, neither race nor racism was part of the syllabus, and in other programs the topic is usually subsumed under ethnic and racial conflicts. The implications of racism, colonialism, and Eurocentrism are mentioned but not often talked about with full honesty and depth, leaving this task to the practitioners of other disciplines. In our classroom, racism was mentioned as a form of structural violence that can be explained according to certain scientific formula of race, gender, class, nation, etc. (GALTUNG, 1996). This approach to racism often creates a volatile situation in classroom situations. Different views on what racism is and what it is not would clash in discussions. "Gender" and "Race" would clash sometimes and some female students of color would hesitantly confess their disapproval of feminism, not realizing that their sentiment was actually against apparent racism in certain brands of feminist theories. In general, a great level of confusion would often emerge from the discussion around race. As the program hosted a number of students from across the world, some of the students came 
from places where the term "race" was best avoided for its strong association with Nazism, while others had daily encounters of what "race" meant in their lived experience. The account of their lived experience as evidence of racism was either dismissed as an extraordinary situation or attributed to the manifestation of structural violence. How may one talk about race when the United Nations Educational Scientific and Cultural Organization (UNESCO) declared in 1950 in the wake of the Second World War that "race" should be considered a social myth as it has been found to be biologically untenable?

The myth of 'race' has created an enormous amount of human and social damage. In recent years it has taken a heavy toll in human lives and caused untold suffering. It still prevents the normal development of millions of human beings and deprives civilization of the effective co-operation of productive minds. The biological differences between ethnic groups should be disregarded from the standpoint of social acceptance and social action. The unity of mankind from both the biological and social viewpoints is the main thing [UNESCO: Statement on Race by Social Scientists] (LAWSON, 1991, p. 1217)

The social constructivity of race had to be accepted in order to promote unity, and since it was socially constructed and is biologically and genetically meaningless, it was not real. Students are often advised to use the inverted commas for writing about race to let the readers know that they do not believe it to be real. However, if it is not real, why would some of our classmates suffer the consequences of it in their everyday lives? Students are sometimes encouraged to believe what they do not believe. What happens when we say one thing, yet on the daily level we live evidence of its contradictions? Such evidence is often collapsed into "exceptions" (GORDON, 2006, p. 73) or removed from epistemology itself. According to Gordon, evidence is social, and - because it is social - it is "subject to the complex exchange of intersubjective activities" (Ibid., p. 29). For evidence to appear, it requires a world of others. Denying a critical relationship to evidence involves bad faith, thus a denial of reality. To assert that racism is a thing of a past, negates implications of coloniality in racism, dismisses it as an aberration of the norm, or puts the blame on the structure. These are all methods of rejecting the problem. Similarly, Gordon notes that

A great deal of effort to study racism is marred by the core problem of self-evasion.
This is partly because the study of racism is dirty business. It unveils things about
ourselves that we may prefer not to know. If racism emerges out of an evasive spirit,
it is hardly the case that it would stand still and permit itself to be unmasked. Race
theorists theorize in a racist world. The degree to which that world is made evident
will have an impact on the question of whether the theorist not only sees but also
admits what is seen (1995, p. ix).

The fundamental importance of Gordon's approach to racism is that he is not afraid to put a human face on it. For Gordon, theorizing about human phenomena and the social world without the presence of the human risks naturalizing oppression. It is a form of bad faith, a lie 
to the self and an escape from responsibility for the problem at hand and its solution, and flight from the social world. Since the social world is dependent on the agency and the generative activities of the individuals, forgetting such facts runs the risk of doing an "inhuman" study of human phenomena (GORDON, 2000, p. 155). Losing the social dimension of the structure leaves one paralyzed from acting. As Gordon says:

\begin{abstract}
Structures set the conditions for us, but do not determine what we will do and the meaning of our various projects in life. This is so by virtue of many of us doing different things and creating new forms of meaning in structurally similar, if not the same, circumstances. The human world is, in other words, lived, and it is creatively so. (GORDON, 2006, p. 18)
\end{abstract}

The recognition of humanity in others involves, for Gordon (1995a), admission of the social dimensions of embodiment. This is related to questions of what it means to be human as openness and freedom. In Gordon's existential phenomenological approach to the human as freedom in the flesh, both oppression and emancipation are not dissociated from the human body as an opening to the social world (2006, pp. 103-105). This manifests as the individual's relation to structures with regard to choices and the options available. Options function as material reality. Oppression involves reducing or exhausting options available for a certain group of people. However, humans always have choices even after options run out. Those choices are directed inward to the self, to the point of extreme introspection. This is an oppressive situation. In Gordon's view, the notion of power is in accordance with his emphasis on the agency and creativity of the human being and her capacity to affect the social world. In oppressive situations, the reach of the individual does not extend beyond her own body. Thus, violence hovers around. On the contrary, when options are available, the outward choices expand the reach of the body, thereby increasing its impact and reach on the social world. This is power, the expansion of the "the ability with the means to make things happen" (GORDON, 2017, p. 41).

If bad faith is an attempt to flee from freedom and responsibility, a mature philosophical anthropology recognizes the complexity and contradictions of living in an adult world. In that world, innocence becomes irrelevant, for the actions required for emancipation imply facing the challenges and assuming the responsibilities that freedom entails, rather than hiding from them (GORDON, 1995a, p. 80). For Gordon, freedom is imbued in human conditions, the manifestation of which is a responsible adult relation with others. It is the basic condition for humans to cultivate a world of relationships where human beings can flourish. This should be distinguished from such freedom that a racist advocates as "freedom 
of speech." That is not freedom but, according to Gordon, a "license" to do whatever one wants to do, which strips one of maturity and responsibility and is thus childish. This is linked to another always implicit and sometimes explicit point in Gordon's reading of the philosophical anthropology of the blues, of Fanon, of the liberation efforts of black people, of the theorist of human science, and of the educator: the question of maturity. In this way, education fosters growth and maturation as maturity means to face reality and take responsibility for it. The decolonizing of classrooms then requires facing this reality, which means sometimes having to go beyond disciplinary boundaries and methodologies, particularly with regard to the study of the human. Taking that into consideration, peace theory and pedagogy need not leave the question of race to other disciplines. Thinking about race and racism is at the core of many subsequent questions that call for a new understanding of human beings and how to study them.

Gordon conceives thought and disciplines as alive, a consequence of "the living reality on which they rest, namely living societies," (GORDON, 2006, p. 8) and thus, exposed to the possibility of decline. At the outset, it must be underscored that Gordon's conception of discipline is not a negative one. By way of John Dewey, Gordon retrieves how disciplines were initially based on a generative conception of power to construct and create knowledge rather than their current function in academia: as power to control and organize knowledge (Ibid., p. 4). It is when the discipline exerts closure on its own scope, when it is reified and replaces the world, that thinking decays, for thinking must be subordinated to reality: "[a] completely thinkable reality would not be reality any longer, but only an addendum to what is possible [in thought]" (Jaspers as quoted in GORDON, 2006, p. 46). This view of thinking as preceding reality, makes it a humbling rather than a conquering activity: "to think, really to think, is to engage the frightening evidence of our own conceptual limitation and to realize, in such limits, the magnitude of all that transcends us" (Ibid., p. 33). The problem takes place when "disciplines lose sight of themselves as efforts to understand the world and have collapsed into the hubris of asserting themselves as the world" (p.8).

In peace studies, peace is seen as the basis of human relations and violence the rupture of the norm (MARTINEZ-GUZMÁN, 2001). Hence, the attention dedicated to theorization of violence has been scant beyond the initial formulations of Johan Galtung addressed above. Some theorists point out the undertheorization or absence of violence in theories of peace (COURTHEYN, 2017). However, others show anxiety for the space that violence is dedicated to in the study of conflicts. Francisco Muñoz (2001), warns peace researchers against the 
"excessive attention to violence" leading to "cognitive schizophrenia". In a similar vein, the editors of Geographies of Peace, argue that while the discipline has been "doing the important task of challenging the moral logic of war, it has failed to develop equally sophisticated theoretical engagements with, and devote sustained empirical research to, peace" (MCCONNELL et al 2014, p. 1). In their conclusion, they specify that, "to be against violence is not necessarily the same as being for peace" (MEGORAN et al, 2014, p. 256). Although we agree with that statement, the problem is that it actually functions as a call for purity, a narrow redefinition of the ethical and epistemic boundaries of the discipline, wherein peace is implicitly reduced to nonviolence (LOYD, 2015).

At a break during a conference on decolonial thought, we approached a peace scholar:

- "What are you working on?

-“On Palestine and decolonization”.

- "Are you using Fanon?"

-"No, no" the scholar answered nervously, somewhat surprised. Later, during his conference he mentioned the "theories of Fanon," probably meaning armed struggle, to refer to outdated approaches to decolonization in contrast to his Gandhian one.

In another situation at a café having an informal chat with a peace philosopher:

- Are you guys reading Fanon? I have not read him, but I have heard that he did not actually defend violence.

There are several problems with this widespread understanding of the discipline. As Gordon points out, disciplinary decadence functions within and without knowledge distinctions; it delimitates a safe terrain and turns it into the world, thereby reducing the exposure of the theorist to questions that can lead her to the way out (Gordon, 2006: 23). The first problem of the call to study peace without violence is that it impedes research on forms of violence that are not accounted in official records for being considered exceptional. Police brutality is one such case, as denounced by both Malcolm X Grassroots Movement, and We Charge Genocide (LOYD, 2015). Another problem is whether such a disciplinary approach of reifying peace is actually in tune with the plight, the demands, and the objectives of oppressed people. In other words, by focusing on a narrow view of peace the theorist may demand the innocence and predetermine the conditions for action of oppressed groups.

This is a common pattern in the treatment of nonviolence. A paradigmatic example is the important study carried out by Erica Chenoweth and Maria Stephan, Why Civil Resistance Works, which documents the great deal of efficacy of nonviolent struggles in contrast to the 
failures of violent approaches in the same situations. Success and failure are measured in terms of the political goals of the corresponding movements. What the authors miss is that in almost every instance there was the coexistence and almost a symbiotic relation between both strategies (WILLIAMS, 2010; COBB JR., 2014; SUTHERLAND and MEYER, 2000). A feature of disciplinary decadence, and the closed system that it fosters, is that it expels failure to the outside, leaving methods and disciplines not only unquestioned but also reinforced:

That they were "disciplinary" stifled every question, subdued every doubt, and removed the subject from the realm of rational discussion. By its nature, the allegation could not be checked up. Even when discipline did not accrue as matter of fact, when the pupil even grew in laxity if application and lost power of intelligent self-direction, the fault lay with him, not with the duty or methods of teaching. (Dewey, as quoted in GORDON, 2006, p. 4)

Gordon (2007) articulates in theological language this phenomenon of blaming the outsider, the student, the black, for the imperfections of the system. Theodicy is the question that arises from the presence of evil given the all-encompassing goodness of god. The answer is to reassert the perfection of god by putting the blame of evil on humans, either for their bad choices or for their lack of divine understanding. For Gordon, the grammar of theodicy remains in today's secular systems. Whether political or epistemic, they replace god. If systems work in a theodicean way, that is, they are complete and just, then the problems and contradictions of the system are moved to the exterior. They are displaced as pathological deviances. These outsiders, rather than facing problems, become the problem themselves. For Gordon, drawing on W.E. B. Du Bois and Frantz Fanon, the double position of black people as both outsiders and insiders carries with it the potential of a broader perspective, a critical dialectic relationship to society that unveils the contradictions of the system.

The work of Frantz Fanon, as a psychiatrist and social theorist, reveals how taking race into consideration in the human sciences does not simply function as another substantive category to be added to the discipline through osmosis; rather it requires a change in the understanding of the human being, with the consequent challenges to the epistemic, methodological and ontological orders. This can be contrasted with Galtung's abstract understanding of social health. Galtung draws a parallel between health studies and peace studies: both follow a movement that goes from diagnosis, to prognosis, to therapy wherein health is understood as peace and violence as disease (1996, p. 1). Galtung refers to systems of actors/cells and talks about well-states and ill-states. At the analytical stage, the researcher must consider "Nature, Human, Social, World, Time, Culture" (GALTUNG, 1996, p. 1) in terms of contexts, conditions and causes. If a well-state becomes an ill-state, the subsequent 
question is whether the system can restore itself or whether intervention is needed. For Galtung, external intervention cannot be considered therapeutic; in contrast, the work of peace is to provide the conditions for the inherent capacities of self-restoration. Therefore, therapy is to restore the system into its previous well-state. Positive peace is preventive rather than curative, it is then the stimulation of the stability of the system that fosters self-restoration even in the presence of symptoms of illness.

Fanon's concern for social and mental health in colonial societies creates a more complicated landscape. For Fanon and Gordon (2006, p. 50), as we understand them, social health cannot precede existence. At the outset, Fanon distinguishes society from biochemical processes, for the human being is "what brings society into being" (2008, p. 4). Out of this sociogenic declaration that links the subjective with the objective, the human as the producer of meaning in a world of other humans, Fanon dealt with the paradox that making a black person mentally healthy in a racist society would mean to attune her to a sick society. Health, being what upholds and legitimates the sick system, led Fanon to question what health means, and therefore, to reflect on how to think about it, especially considering that the tools available for reflection and practice were colonial in nature. Therefore, neither reflection nor practice could be carried out without considering power. Fanon answered those questions, firstly, through rejecting the dialectics of recognition. The ethical relations that Galtung presupposes are absent in a racist society. The "zone of nonbeing" (FANON, 2008, p. 2), is that region where the ethical relations between self and other are not applied to the black person, but it is also by thinking from this underside that enables a critical perspective and shelters the possibility of a new society. The task envisaged by Fanon is for the black to become actional rather than passive or merely reactive (2008, pp. 119, 173), and the goal is "to set up institutions permeated by care for human beings" (FANON, 1967, p. 53).

However, an important aspect of Fanonian thought that Gordon (2015, p. 114) highlights, and which is also part of the Africana political experience, is that by being actional and expanding the scope of influence and intervention in the world, the very existence of the black becomes violence in an anti-black society. Those "illicit appearance[s]" could not afford to rely on the ethics of the society to sustain their claims, for relying on what is good would imply accepting the legitimacy of the system that keeps them outside. The task at hand is a political one which, etymologically, is the form of dealing with conflict through communication rather than war. However, this is a double task for those who are excluded from the realm of politics and whose political appearance is seen as violence, for they must do 
politics with the purpose of creating politics sustained by ethical relationships (GORDON: 2008, pp. 86-89). In this view, Galtung's telescopic model of social health, without considerations of history, power asymmetries, and assuming the intrinsic legitimacy of the society, might lead to maintaining the status quo.

There are uncomfortable dimensions to the problem which those in power will be
unwilling to address - unwillingly, ultimately, because they are used to having
other's cake and eating it, too - and one of these dimensions is the legitimation
crisis [...]: the very conditions that they may place upon the praxis of oppressed
people may ultimately be conditions that will make no difference. (GORDON,
1995a, p. 78)

The questions of legitimacy and conditionality that peace studies has decided not to ask are the questions emerging from the underside. Fanon was not the only one. From the anti-colonial revolution in Haiti to the Civil Rights, Black Consciousness or the current movements of Black Lives Matter, or shack dwellers in postapartheid South Africa (GIBSON, 2011), those struggling for liberation realize that the dialectics of recognition are not conducive to change, and could not afford to rely on a priori notions of what they shall do, what will function or what will fail.

Although geopolitical criticism of the intrinsic violence of the liberal peace paradigm abound, peace studies seems to assume that by reformulating and rethinking the concept of peace, and consequently the approach to reality, the conditions of the oppressed shall be different. But among the questions that black liberation movements have been asking is what happens if and when peace, justice or human rights are not enough, when they function as sentinels of social change for those in power? The paucity of engagement with black liberation and anti-colonial movements, except for those of Martin Luther King Jr. and Mahatma Ghandi, and the treatment of those movements as a thing of the past, reveals that if one does not ask, maybe it is because one does not want to hear the answer.

Galtung's initial distinction between positive and negative peace has elicited much reflection on alternative conceptualizations of peace, partly because of the vagueness of the concept itself. On one side, there have been explorations of the meaning of peace across cultures (DIETRICH et al. 2011, FRYE, 2007). On the other side, philosophical and interdisciplinary reformulations of the concept of peace have been advanced. Among the latter, Francisco Muñoz's idea of imperfect peace proposes a view of peace as an incomplete, imperfect process in which conflict is an integral part. This conception stands in contrast to the common view of peace as a static and unachievable ideal. For Muñoz, imperfect peace is "a process between negative peace and positive peace, between the absence of violence and 
the preeminence of justice" (2001, p. 12). For Muñoz, this notion seeks to highlight ordinary moments of positivity for peace research epistemology, to recognize peaceful practices amidst structural and direct violence, to prepare the terrain for the conflictive and imperfect quality of the future, and to overcome the peaceful/violent dualism by looking at intermediate situations. Further, he takes peace theorists to task for the lack of attention to power, concretely, “peaceful power taking” (MUÑOZ, 2001).

This is a valuable formulation in terms of the disciplines' goals. It enables us to recognize the complex dynamics of peace and violence, and apparently solves the theodicean dimension of peace, wherein violence would be extra-systemic. The problem with that perspective is that the theorist presupposes that human beings think in terms of a single element - peace - as a way of negotiating their relations, and that they have stable objectives, attitudes and choices. But what if those objectives and attitudes are different, or change because of their interactions in the social world, or because of historical impositions? We cannot know, basically because as in the case of structural violence above, the theorist presents a world without humans. If part of what incompleteness entails is an opening of possibilities and directions, one wonders if this avowal of the imperfection of peace is another form of asserting the perfection of the new system. In Gordon's view, by

admitting the injustice of the system and showing how it could be made good, the
logic of ultimate goodness is inscribed in the avowed range of the all-enveloping
alternative system. Such a new system's rigor requires, in effect, the elimination of
all outsiders by virtue of their assimilation. (GORDON, 2007, p. 122)

At the heart of Gordon's warning against disciplinary decadence does not lie a concern for the health of the disciplines for their own sake. Instead, the center of Gordon's preoccupation is the relationship of human beings as knowers and producers of knowledge to a broader reality, which as we have seen, exceeds and precedes thought. It is a relation of humility and expansion rather than of conquering and reduction. To overcome that, Gordon does not propose interdisciplinarity, where untouched disciplines work together while running parallel to each other, but a "teleological suspension of disciplinarity" (2006, p.44). To ensure the vitality of thought entails the humbling realization that reality is "infinitely bigger than us" (Ibid, p. 45). It also requires the maturity to face the challenges and the complexity of human reality by taking responsibility for it. The result is an opening to new knowledge interactions and relationships that can lead to new and broader disciplines.

\section{Concluding Remarks}


This paper does not suggest an incompatibility between Lewis Gordon or Africana theorists and peace studies. On the contrary, it suggests the need to engage other disciplines beyond assimilationist approaches and predetermined outcomes. The vitality of thought requires dialogue and, therefore, listening. Dialogue is an important dimension in the theory and praxis of peace studies. However, Gordon emphasizes the difference between listening and admitting what is being listened to. The latter can entail questioning the listener's own assumptions through which the transformation of meanings, values and relationships can begin. As human beings are fundamentally relational and open possibilities, supporting freedom of thought also requires that disciplines relate in such a way, as sites of transdisciplinary communication and creation for the actual purpose of thinking, which is meant to serve all humans facing challenges and conflicts.

\section{References}

ANGHIE, Antony. Imperialism, sovereignty and the making of international law. Cambridge: Cambridge University Press, 2004.

ANIEVAS, Alexander et al. Race and racism in international relations. New York: Routledge, 2015.

CHENOWETH, Erica and STEPHAN, Maria J. Why civil resistance works. The strategic logic of nonviolent conflict. New York: Cambridge University Press, 2011.

COBB JR, Charles E. This nonviolent stuff'll get you killed. How guns made the civil rights movements possible. New York: Basic Books, (2014).

COURTHEYN, Christopher. Peace geographies: Expanding from modern-liberal peace to radical trans-relational peace. Progress in Human Geography, v. xx, n. x, 1-18, 2017.

DIETRICH, Wolfgang et al. The Palgrave international handbook of peace studies. A cultural perspective. London: Palgrave Macmillan, 2011.

FANON, Frantz. (2008): Black skin, white masks. Translated by C. L. Markmann. London: Pluto Press, 2008.

FANON, Frantz. Toward the African Revolution. Translated by Haakon Chevalier. New York: Monthly Review Press, 1967.

FRY, Douglas P. Beyond War: The Human Potential for Peace, New York, OUP, 2007.

GALTUNG, J. Peace by peaceful means. Peace and conflict, development and civilization . Oslo / Thousand Oaks, CA: International Peace Research Institute/ SAGE, 1996. 
GIBSON, Nigel C. Fanonian practices in South Africa: From Steve Biko to Abahlali baseMjondolo. Scottsville: University of KwaZulu-Natal Press, 2011.

GORDON, Lewis Ricardo. Bad faith and antiblack racism. New York: Humanity Books, 1995.

GORDON, Lewis Ricardo. Fanon and the crisis of the European man: An essay in philosophy and the human sciences. New York: Routledge, 1995a.

GORDON, Lewis Ricardo. Existentia Africana: Understanding Africana existential thought. New York: Routledge, 2000.

GORDON, Lewis Ricardo. Disciplinary decadence: Living thought in trying times. Boulder, CO: Paradigm, 2006.

GORDON, Lewis Ricardo. Problematic people and epistemic decolonization: Toward the postcolonial in africana political thought, in PERSAM, Nalini. (ed.) Postcolonialism and political theory. Plymouth: Lexington Books, 2007, (121-142)

GORDON, Lewis Ricardo. A phenomenology of Biko's Black Consciousness, in Mngxitama, A. et al. (eds). Biko vives! Contesting the legacies of Steve Biko. New York: Palgrave Macmillan, 2008.

GORDON, Lewis Ricardo. What Fanon said. A philosophical introduction to his life and thought. New York: Fordham University Press, 2015.

GORDON, Lewis Ricardo. Cities and citizenship. Kettering Review. 34(1), 36-43., 2017

LOYD, Jenna. Book review of Geographies of Peace. Antipode: A radical journal of geography. 2015. https://antipodefoundation.org/2015/04/29/geographies-of-peacel

MEGORAN, Nick Solly. et al. Geographies of peace, geographies for peace. In: MC CONELL, Fiona et al. (eds). Geographies of Peace. London: I.B. Tauris, 2014, (250-260).

MALDONADO-TORRES, Nelson. Lewis Gordon: Philosopher of the Human. CLR James Journal, v.14, n.1. p.103-137, 2008.

MUÑOZ, Francisco. La paz imperfecta. Granada: Universidad de Granada, 2001.

MUÑOZ, Francisco. 2006. Imperfect Peace in Dietrich, W., Echavarria, Alvarez, J. \& Koppensteiner, N.(Eds.). Key Texts Of Peace Studies. Wien: LIT-Verlag, 241--281.

NIRENBERG, David. et al. Race and Blood in the Iberian World. Berlin: Lit Verlag, 2012.

SUÁREZ-KRABBE, Julia. Race, Rights and Rebels: Alternatives to Human Rights and Development from the Global South. London: Rowman \& Littlefield International, 2015.

SUTHERLAND, Bill and MEYER, Matt. Guns and Gandhi in Africa: Pan-African insights on nonviolence, armed struggle and liberation. Trenton: Africa World Press, 2000.

WILLIAMS, Philippa. et al. (2014). Introduction: Geographical approaches to peace. MC CONELL, Fiona et al. (eds). Geographies of Peace. London: I.B. Tauris, 2014, (1-28) 
WILLIAMS, Randall. The divided world: Human rights and its violence. Minneapolis: University of Minnesota Press, 2010.

LAWSON, Edward H. et al. Encyclopedia of Human Rights. Washington DC: Taylor \& Francis, 1991. 